\title{
Screening Coconut Cultivars for Tolerance to Infestation by the Coconut Mite, Aceria guerreronis (Keifer) in Sri Lanka
}

\author{
L. Perera ${ }^{1}$, S.R. Sarathchandra ${ }^{2}$ and I.R. Wickramananda ${ }^{3}$
}

\begin{abstract}
The coconut mite (Aceria guerreronis Keifer) is a tiny pest which severely damages the nuts of the coconut palm (Cocos nucifera Linnaeus). At present there is no appropriate control method for this pest in Sri Lanka. Field observations have revealed difference in the severity of A. guerreronis mite infestation among selected and improved coconut cultivars in Sri Lanka. This difference has not been studied in depth and therefore the present study was conducted to investigate the levels of tolerance in selected and improved coconut cultivars and, if differences were demonstrated, to understand the mechanism behind the tolerance. A replicated trial in Thammenna Estate (TE) in Puttalam district in Sri Lanka, where the mite infestation was natural and severe, was selected for this study. The trial was planted in 1983 and consisted of two improved coconut cultivars; Sri Lanka Yellow Dwarf x Sri Lanka Tall (YDT) and Sri Lanka Green Dwarf x Sri Lanka Tall (GDT) and the selected Sri Lanka Tall cultivar (TT) which has, green (TTG) and russet coloured (TTR) forms. Population assessment of mites on immature nuts, damage initiation of the fourth bunch and harvest records were obtained. Further, characters that were thought to influence tolerance, such as nut shape as measured by ratio of length to breadth, the tightness of perianth to the nut surface and some changes in the affected tissues were also recorded. Yield data were collected for each cultivar to estimate the crop loss due to coconut mite damage. The results revealed that out of the cultivars tested in this trial, YDT had the lowest incidence of mite colonization and the smallest mite population size and symptom initiation compared to others. The distance between the perianth and nut surface, the least in YDT, is suggested as the most probable morphological feature that would impart tolerance to mite infestation.
\end{abstract}

Keywords: Coconut, Cocos nucifera Linnaeus, tolerance, resistance, mite infestation, Aceria guerreronis Keifer

\footnotetext{
${ }^{1}$ Genetics \& Plant Breeding Division, Coconut Research Institute, Lunuwila, Sri Lanka.

${ }^{2}$ Faculty of Agriculture, University of Ruhuna, Sri Lanka (Graduate student).

${ }^{3}$ Crop Protection Division, Coconut Research Institute, Lunuwila, Sri Lanka (Present address: SGS Agrifood Laboratories, 1-503 Imperial Road North, Guelph, N1H 6T9 ON, Canada).

Corresponding author: L Perera

Email: lalithperera1234@yahoo.com

Phone: 0094-71-3127954
} 


\section{Introduction}

The coconut mite, Aceria guerreronis Keifer, attacks young fruits of the coconut palm (Cocos nucifera L.). The mites are microscopic, with the largest stage around $200 \mu \mathrm{m}$ in length, but they often build up extremely large and dense populations. Their feeding causes scarring and distortion of the fruits, and may cause premature fruit drop. The coconut mite is a serious pest in 17 coconut growing countries including Benin (Mariau and Julia, 1970); Ivory Coast (Julia and Mariau, 1979); Colombia (Zuluaga and Sanchez, 1971); Mexico (Hall and Espinosa, 1981); India (Sathiamma et al., 1998) and Sri Lanka (Fernando, 1998). The coconut mite was first reported in Kalpitiya area in Sri Lanka in 1997 and rapidly spread into some other major coconut growing areas of the country, thus becoming a serious concern to the coconut growers in Sri Lanka (Fernando et al., 2002). The coconut crop loss due to coconut mite in Sri Lanka was estimated to be around 16\% (Wickramananda et al., 2007). Chemical pesticides, plant extracts and used engine oil have been applied to try to control coconut mite in Sri Lanka (Fernando, 2006; 2007; 2008) but they were not practical or cost effective for large scale applications. There are reports on the possibility of natural or bio-control of the pest by predators (Fernando et al., 2003), but the slow rate of multiplication in the natural environment and poor self distribution of the predator from one palm to the other are still limitations in the use predators for effective control of the mite. Due to the biological nature of both the pest and the host no effective control method for this problem has so far been identified anywhere in the world. As a result, it was felt that screening or breeding coconut cultivars for mite resistance/tolerance is important for a sustainable solution for the problem.

Coconut varieties differ in their susceptibility to coconut mite. The coconut varieties most common in Florida and the Caribbean, viz., 'Jamaica Tall', 'Panama Tall', 'Malayan Yellow Dwarf', and 'Malayan Green Dwarf' are all highly susceptible to coconut mite while some observers have reported certain varieties of coconut appear to be resistant, viz., an apparently resistant Cambodian variety (Howard, 2006) and less susceptible Gangabondam variety in India (Girisha and Nandihalli, 2009). It was suggested that the very round shape of the fruit of Cambodian variety perhaps resulted in a tight perianth which prevent mites entering into the inner surface of the perianth for causing damage, but the presence of repulsive bio-chemicals governed by genetic factors could not be excluded, as some workers have observed extensive damage of coconut mites on round-fruited coconut varieties in Florida and the Caribbean (Howard, 2006).

The Sri Lanka coconut breeding program has released Ambakelle Tall (TT-TTG and TTR), developed by rigorous selection from Sri Lanka Tall (SLT) for yield, Yellow Dwarf $\mathrm{x}$ Ambakelle Tall (YDT) and Green Dwarf $x$ Ambakelle Tall (GDT). These latter two cultivars have been developed by hybridization between local dwarf coconut cultivars and local tall coconut cultivars.

Coconut cultivars have been planted in a systematic cultivar evaluation trial in Thammenna Estate (TE) in Puttalam District in the dry zone of the country in Sri Lanka in 1983. These cultivars have never been adequately studied for pest resistance or tolerance but field observations revealed a difference in the severity of coconut mite infestation among these different cultivars. This inspired the interest to initiate a study to screen these selected coconut cultivars in detail for mite resistance/tolerance with, the objective of recommending resistant or tolerant coconut cultivars for the mite infested areas to combat the pest in a sustainable manner. Since there was a report that dark green nuts tend to have greater resistance to coconut mite (Moore and Alexander, 1990) and since there was a belief in Sri Lanka that the "Russet" colour form of Sri Lankan tall shows some tolerance to coconut mite, a group of 20 palms each of green (TTG) and russet (TTR) forms within TT were considered separately for this study.

\section{Method and Materials}

Commercially recommended coconut cultivars viz., TT (TTG and TTR), YDT and GDT were planted in a randomized complete 
block design in 1983 in the TE trial to compare the performance of these cultivars in the dry zone. The number of blocks (replicates) in the experiment was four and the number of palms per plot in a single block was twenty. The planting density of the experiment was 200 palms per hectare in a triangular design with spacing of $7.6 \times 7.6 \times 7.6 \mathrm{~m}$. As the trial had been planted in the dry zone of the country, the mite infestation was naturally high. The data were recorded from every one of five randomly selected palms from each block (20 palms of each in total) which were naturally infested.

Damage assessment was assessed by the percentage of damaged nuts in the four month old bunch on the palm and harvest record of 1112 month old bunches of each palm of the experiment were individually obtained. Total mite count per nut was estimated by the wash count method (Siriwardana, 1999). Crop loss at harvest was recorded at each harvest taking into consideration, the undamaged nuts; mite damaged nuts and within the mite damaged nuts; the normal, deformed and barren nuts. All data were collected three times in consecutive months.

Two characters that might affect tolerance were investigated. These characters were nut shape as measured by ratio of length to breadth and the tightness of perianth to the nut surface as measured by the mean distance between nut surface and the perianth.

\section{Results}

\section{Total coconut mite population:}

There was a significant difference $(\mathrm{P}<0.05)$ in the total coconut mite population between the cultivars during the first and second record but not in the third record according to the Duncan's multiple range test. The lowest level of mite population was observed in YDT in the first and second record while other cultivars in the same months showed significantly higher mite counts (Table 1).

\section{Percentage damaged nuts:}

A significant difference $(\mathrm{P}<0.05)$ in the percentage of damaged nuts between the four cultivars was observed during the first and second records but not in the third record. The lowest damage was again recorded in YDT. The other cultivars had no difference at any time (Table 2).

\section{Percentage crop loss:}

The percentage crop loss at harvest was analyzed using ANOVA. A significant difference $(\mathrm{P}<0.05)$ among the four cultivars was evident and the Duncan's multiple range test clearly indicated that the lowest mean crop loss was attributed to the cultivar YDT (Fig. 1).

\section{Distance between nut surface and the perianth of the nuts}

The mean distance between nut surface and the perianth of the four cultivars was analyzed using ANOVA. The differences of mean values were highly significant among the four cultivars according to Duncan's multiple range test. The cultivar, YDT had the lowest distance (Table 3) but was statistically significant only in the second and third records.

\section{Length: Width ratio of the nuts}

Results of this study clearly indicated a significant difference between the four cultivars in the ratio of length and width of the nuts in the third bunch. YDT had the lowest ratio at all times but the significance varied at different months (Table 4).

\section{Discussion}

The study indicated that the mean total coconut mite population levels, damage initiation, and the crop loss due to mite damage were least in YDT indicating the highest tolerance of YDT to the coconut mite. The tolerance level decreased in the order of GDT, TTR and TTG respectively. There was a significant difference $(\mathrm{P}<0.05)$ in the total mite count between the four cultivars studied for the first and second counts. The lowest mite count was observed for YDT (70.5 and 76.5 in first count and second count respectively) compared to other cultivars (ranged between 213 -535.5). A similar trend was observed for the percentage of damaged nuts. The lowest damage was recorded in YDT $(9.1 \%)$ compared to other 
Table 1. Mean total population of coconut mite on 4 month old nuts in different cultivars

\begin{tabular}{|l|r|r|r|}
\hline \multicolumn{1}{|c|}{ Cultivar } & $1^{\text {st }}$ Record & $2^{\text {nd }}$ Record & $3^{\text {rd }}$ Record \\
\hline YDT & $70.5^{\mathrm{c}}$ & $76.5^{\mathrm{b}}$ & $310.5^{\mathrm{a}}$ \\
GDT & $213.0^{\mathrm{b}}$ & $298.5^{\mathrm{a}}$ & $438.0^{\mathrm{a}}$ \\
TTG & $535.5^{\mathrm{a}}$ & $477.0^{\mathrm{a}}$ & $547.5^{\mathrm{a}}$ \\
TTR & $364.5 \mathrm{~A}^{\mathrm{b}}$ & $310.5^{\mathrm{a}}$ & $520.5^{\mathrm{a}}$ \\
\hline Coefficient of Variance & 76.6 & 79.6 & 62.3 \\
Coefficient of correlation $\left(\mathrm{R}^{2}\right)$ & 0.24 & 0.24 & 0.23 \\
\hline
\end{tabular}

Means with the same letter in a column are not significantly different $(\mathrm{P}<0.05)$

Table 2. Percentage of damaged nuts on the 4-month old bunch in different cultivars

\begin{tabular}{|l|r|r|r|}
\hline \multicolumn{1}{|c|}{ Cultivar } & $1^{\text {st }}$ Record & $2^{\text {nd }}$ Record & $3^{\text {rd }}$ Record \\
\hline YDT & $9.10^{\mathrm{b}}$ & $05.25^{\mathrm{b}}$ & $28.30^{\mathrm{a}}$ \\
GDT & $37.92^{\mathrm{a}}$ & $19.79^{\mathrm{a}}$ & $41.91^{\mathrm{a}}$ \\
TTG & $42.71^{\mathrm{a}}$ & $37.80^{\mathrm{a}}$ & $46.02^{\mathrm{a}}$ \\
TTR & $29.23^{\mathrm{a}}$ & $28.04^{\mathrm{a}}$ & $27.15^{\mathrm{a}}$ \\
\hline Coefficient of Variance & 74.16 & 77.79 & 62.59 \\
Coefficient of correlation $\left(\mathrm{R}^{2)}\right.$ & 0.19 & 0.24 & 0.058 \\
\hline
\end{tabular}

Means with the same letter are not significantly different $(\mathrm{P}<0.05)$

Table 3. Mean distance $(\mu \mathrm{m})$ between nut surface and perianth

\begin{tabular}{|l|r|r|r|}
\hline \multicolumn{1}{|c|}{ Cultivar } & $1^{\text {st }}$ Record & $2^{\text {nd }}$ Record & $3^{\text {rd }}$ Record \\
\hline YDT & $13.438^{\mathrm{c}}$ & $10.718^{\mathrm{c}}$ & $09.125^{\mathrm{c}}$ \\
GDT & $19.406^{\mathrm{a}}$ & $19.375^{\mathrm{a}}$ & $18.906^{\mathrm{a}}$ \\
TTG & $16.063^{\mathrm{b}}$ & $18.141^{\mathrm{a}}$ & $17.313^{\mathrm{b}}$ \\
TTR & $14.813^{\mathrm{bc}}$ & $15.531^{\mathrm{b}}$ & $15.438^{\mathrm{b}}$ \\
\hline Coefficient of variance & 20.48 & 23.89 & 31.46 \\
Coefficient of correlation $\left(\mathrm{R}^{2}\right)$ & 0.3258 & 0.4399 & 0.3883 \\
\hline
\end{tabular}

Means with the same letter are not significantly different $(\mathrm{P}<0.05)$

Table 4. Mean length to width ratio of the nuts of four cultivars

\begin{tabular}{|l|r|r|r|}
\hline \multicolumn{1}{|c|}{ Cultivar } & $1^{\text {st }}$ Record & $2^{\text {nd }}$ Record & $3^{\text {rd }}$ Record \\
\hline YDT & $1.34090^{\mathrm{b}}$ & $1.34360^{\mathrm{b}}$ & $1.51357^{\mathrm{b}}$ \\
GDT & $1.38675^{\mathrm{ba}}$ & $1.42439^{\mathrm{b}}$ & $1.58835^{\mathrm{ba}}$ \\
TTG & $1.36464^{\mathrm{ba}}$ & $1.60856^{\mathrm{a}}$ & $1.60856^{\mathrm{a}}$ \\
TTR & $1.45458^{\mathrm{a}}$ & $1.58835^{\mathrm{a}}$ & $1.66520^{\mathrm{a}}$ \\
\hline Coefficient of variance & 10.96 & 9.69 & 8.41 \\
Coefficient of correlation $\left(\mathrm{R}^{2}\right)$ & 0.0757 & 0.3836 & 0.1470 \\
\hline
\end{tabular}

Means with the same letter are not significantly different $(\mathrm{P}<0.05)$ 
Figure 1. Mean percentage crop loss in the four cultivars

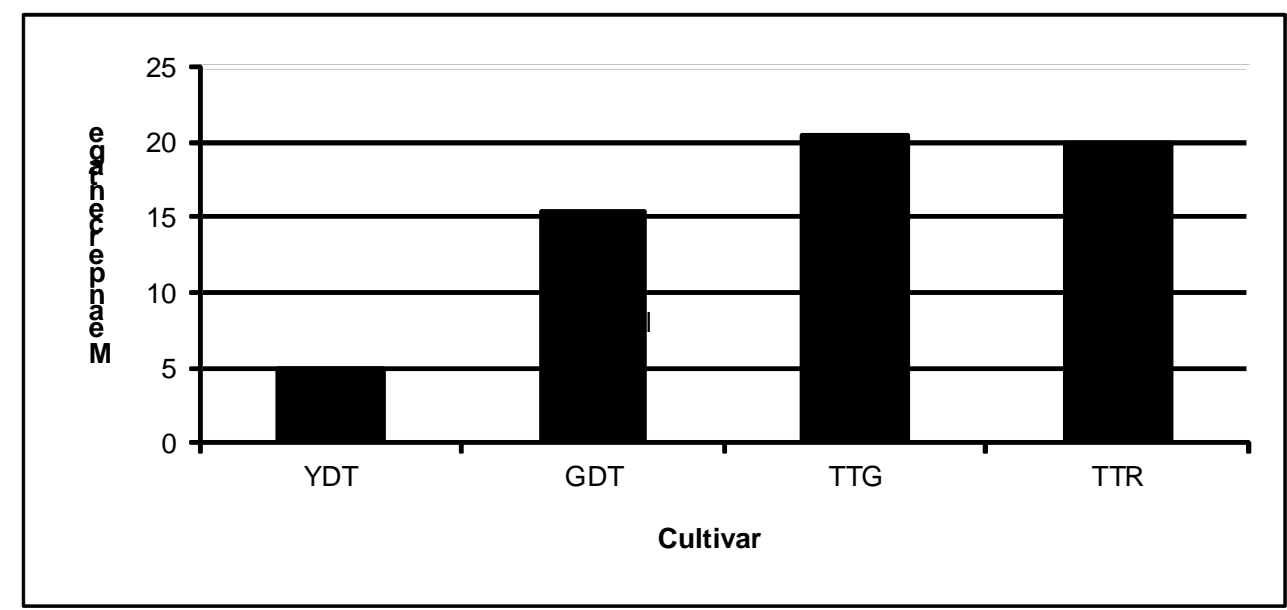

cultivars (ranged between 19.79\% - 77.79\%). The results of the data analysis carried out for percentages crop loss due to mite damage at harvest, clearly indicated that the lowest mean crop loss was evident in YDT (5\%) compared to between $15 \%$ to $20 \%$ in other cultivars tested. The study further indicated that the mean total coconut mite population levels, damage initiation, and the crop loss due to mite damage were found to be the least in YDT and hence YDT had the highest tolerance to coconut mite.

In a previous, unpublished, study comparing coconut mite resistance/tolerance in coconut varieties indigenous to Sri Lanka a greater degree of tolerance to A. guerreronis was found in the varieties, Sri Lanka Yellow Dwarf (SLYD) and Gon Thembili (GT) compared to other varieties (Perera, 2005; unpublished data). Thus the tolerance of YDT is probably inherited from the parent, Sri Lanka Yellow Dwarf (SLYD).

The mean distance between nut surface and the perianth of the four coconut cultivars studied in this experiment clearly shows significantly high difference in the mean distance between nut surface and perianth averaged over three months in YDT $(11.09 \mu \mathrm{m})$ compared to the average of other cultivars averaged over the same period $(17.22 \mu \mathrm{m})$. Although the length to width ratio of the nuts indicated a significant difference between the four coconut types, it was observed that the level of significance varied at different months, indicating not as much of a significance of the shape of the fruit in explaining the mechanism of resistance.

There have been observations of extensive damage of coconut mites on round-fruited coconut varieties in Florida and the Caribbean (Howard, 2006). The distance between the perianth and nut surface, the least in YDT, could be thus suggested as the most probable morphological feature that would impart tolerance of YDT to the coconut mite.

It has been suggested that colour, size and shape of the fruit; tightness of the perianth to the fruit and the presence of some defensive biochemicals governed by genetic factors as a defensive mechanism could be the reasons for the general observation of resistance/tolerance palms in the field. The results of this trial do not show any difference attributable to fruit colour while biochemical factors were not investigated.

\section{Conclusion}

The coconut hybrid Sri Lanka Yellow Dwarf $x$ Sri Lanka Tall (YDT) was found to show greater tolerance to coconut mite, Aceria guerreronis in Sri Lanka compared to other commercially cultivated coconut cultivars in the country. Hence this hybrid can be recommended for planting in mite infested areas in order to reduce the crop loss due to A. guerreronis. The 
distance between the perianth and nut surface, the least in YDT, could be suggested as the most probable morphological feature that would impart tolerance of YDT to A. guerreronis. A detailed investigation involving all coconut varieties/cultivars and all possible morphological and biochemical attributes of fruits is suggested for identification of more tolerant varieties/ cultivars and for further confirmation of the mechanism of tolerance.

\section{Acknowledgement}

The authors wish to thank Dr. Hugh Harries, UK for his valuable comments on the manuscript and for proof reading.

\section{References}

Fernando, L.C.P. 1998, 2006, 2007, 2008. Reports, Crop Protection Division, Annual Reports, Coconut Research Institute, Sri Lanka.

Fernando, L.C.P., Wickramananda, I.R. and Aratchige, N.S. 2002. Status of coconut mite, Aceria guerreronis in Sri Lanka, pp. 1-12. In: Proceedings of the International Workshop on Coconut mite (Aceria guerreronis). L.C.P. Fernanado,. G.J. de Moraes, I.R. Wickramananda (Eds.), Coconut Research Institute, Sri Lanka, 6-8 January 2000, (published in 2002), 117pp.

Fernando, L.C.P., Aratchige, N.S. and Peiris, T.S.G. 2003. Distribution pattern of coconut mite Aceria guerreronis and its predator Neoseiulus aff. paspalivorus on coconut palms. Exp. Appl. Acarol. 31:7178 .

Girisha, R.C. and Nandihalli, B.S. 2009. Seasonal abundance and varietal reaction of coconut perianth mite, Aceria guerreronis Keifer in Dharwad area. Karnataka J. Agric. Sci. 22: 606-608.

Howard, F.W. 2006. http://entnemdept.ufl.edu/ creatures/orn/palms/Aceria_guerreronis.htm

Hall, R.A. and Espinosa, B.A. 1981. The coconut mite, Eriophyes guerreronis, with special reference to the problem in Mexico, pp. 113-120. In: Proceedings, 1981 British
Crop Protection Conference - Pests and Diseases, British Crop Protection Conference, Farnham, U.K.

Julia, J.F. and D. Mariau. 1979. Nouvalles recherches en Cote d'lvoir sur Eriophyes guerreronis.

K., acarien ravageur des noix du cocotier. Oléagineux 34:181-189.

Mariau, D. and Julia, J.F. 1970. L'acariose Aceria guerreronis (Keifer), ravageur du cocotier. Oléagineux 25: 459-464.

Moore, D. and Alexander, L. 1990. Resistance of coconuts in St. Lucia to attack by the coconut Mite, Eriophyes guerreronis Keifer. Trop. Agric. 67:33-36.

Perera, L. 2005. Report of the Genetics and Plant Breeding Division. Annual Report of the Coconut Research Institute, Sri Lanka.

Sathiamma, B., Radhakrishnan Nair, C.P. and Koshy, P.K. 1998. Outbreak of a nut infesting eriophyid mite Eriophyes guerreronis $(\mathrm{K}$.$) in coconut plantations in$ India. Indian Coconut J. 29: 1-3.

Siriwardana, P.H.A.P. 1999. Development of a new technique to estimate the population of coconut mite Aceria guerreronis Keifer (Acari: Eriophyidae) in a single nut. B.Sc thesis, University of Peradeniya, Sri Lanka.

Wickramananda, I.R., Peiris, T.S.G., Fernando, M.T.N., Fernando, L.C.P. and Edgington, S. 2007. Impact of the coconut mite (Aceria guerreronis Keifer) on the coconut industry in Sri Lanka. CORD 23: 1-16.

Zuluaga, C.I. and Sanchez, P.A. 1971. La rona o escoriacion de los frutos de cocotero (Cocos nucifera) en Colombia. Oléagineux 26: 767-770. 